\title{
CORRUPTION AND ITS IMPACT ON THE ECONOMIC PERFORMANCE OF REGIONS OF THE CZECH REPUBLIC
}

\author{
[Korupce a její dopad na ekonomickou výkonnost regionů České republiky]
}

\author{
Veronika Linhartová ${ }^{1}$ \\ ${ }^{1}$ Univerzita Pardubice, Fakulta ekonomicko-správní, Studentská 95, 53210 Pardubice \\ Email:veronika.linhartova@upce.cz
}

\begin{abstract}
The article deals with corruption and its possible impact on the economic performance of sub-national units. This topic has been missing regional dimension until now. In spite of the fact that many exact procedures which try to quantify the corruption rate in a country already exist, they all focus without exception on corruption rate at the level of countries. The newly proposed Regional index of corruption for quantification regional corruption rate will be introduced. It will be possible to mutually compare the individual regions from final values, to specify more or less affected regions, eventually to quantify deviations of individual regions from surface rate of corruption by using mathematical and statistic methods. Using the calculations of the corruption rate there was analyzed the possible impact of corruption on economic performance of NUTS II regions of the Czech Republic.
\end{abstract}

Keywords: corruption, economic performance, regional disparities, regions, Transparency International.

JEL Classification: D73, H11

Doručeno redakci: 11.9.2015; Recenzováno: 8.10.2015; 3.11.2015; Schváleno k publikování: 26.5.2016

\section{Introduction}

Despite the fact that corruption is not a new phenomenon and many authors, especially the foreign ones, have been dealing with this subject intensively for many years, there are still many questions that remain unanswered. Especially the question of quantification of the corruption rate invokes stormy discussions. Regarding the fact that bribery and other ways of corruption acting are illegal in most countries, their participants try to hide them very thoroughly and corruption reveal is often almost impossible. Despite that a high number of exact procedures exist nowadays. These procedures try to quantify the corruption rate in a country. A common feature of these methods is however that they focus on corruption rate at the level of countries. Socio-economic development in countries is not homogeneous. It can be assumed that the corruption level differs in individual regions within the country. Subnational areas which are more corrupted deteriorate rating of the corruption level in the whole country. Quantification of corruption rate in smaller regional areas is still a considerably unexplored sphere not only in the Czech Republic but all over the world. Also the definition of the potential impacts of corruption or their precise quantification is an area that has been investigated only in the general level of the state.

The main goals of this paper are formulated in this context, which is an introduction of a new method for quantification regional corruption rate, comparison of individual Czech regions and identification of those which are more affected by corruption than the others. Using the calculations of the corruption rate there will be analyzed the impact of corruption on economic performance of NUTS II regions of the Czech Republic. 


\section{Corruption and its impact on economic performance}

Corruption represents an unfair acting with the goal of gaining a certain incompetent advantage at the expense of others. The meaning of the word "advantage" can have various forms. It does not regard only an advantage of a financial type, i.e. bribe, but it has often the form of gaining worth information, incompetent acknowledgment or important position. Transparency International (2013), international nonprofit organization whose function is to map the status of corruption and to contribute actively with its operation to corruption limitation, defines corruption similarly to „misuse of a public function for the purpose of private enrichment".

\subsection{Impact of corruption on economic performance}

Isn't even corruption the cause of wealth of some states? Isn't corruption of what "nobbles" the economy because it enables individuals to avoid bureaucratic suspensions and administrative delays? Or is corruption "sand in wheels" and makes economic transactions difficult by decreasing the security of property rights and allocates resources incorrectly? The question if corruption can influence the economic level of states and their economic growth isn't answered without controversies in studies. But the author of this articel supposes that in case of the existence of an adequate legislation, the argument of corruption as "slush" (arguments ,grease “ or ,,speed money " are also used) of economy is unacceptable.

According to many studies corruption has a precisely quantifiable negative impact on economic performance and economic growth of the state. Mauro (1995) concludes that the impact of corruption through exposure to the investment is considerable. In a sample of 67 countries for the period 1960-1985 showed that two points improvement in the perception of corruption (on a scale of 0-10) leads to an increase in investment by 4 percentage points and in GDP growth per capita by half a percentage point per year. The negative effects of corruption on the area of foreign investment, Shleifer and Vishny (1993) state on the example of the Russian economy in the 90's. Foreign investors need to pay bribes at any level of bureaucracy, which dicourage them from investing in Russia. These phenomena occur predominantly in economies with weak government and non-functioning institutional system. Mo (2001) used in his study a long-term development of GDP per capita and presented an estimate of "direct" impact of corruption and "indirect" impact of various portable channels such as investment, human capital and political instability through which corruption may affect economic growth. Mo by using a regression analysis shows that the increase in the CPI by one unit reduces the growth rate by about 0.5 percentage points and leading portable channel is political instability, which is responsible for 53 percent of the total effect. Liu (1985) argues that the bribes would speed up the administration only in that case if the officials did not have to give up partly in favor of higher instances, such as supervising management or politicians threatening to close their position due to inefficiency. Otherwise corruption is a negative externality in a form of a slowdown bureaucracy. Lambsdorff (2001) is of the opinion that the final impact of corruption depends precisely on the extent of these externalities. They may ultimately hit the surrounding areas and most often negatively affect other competitors. Lambsdorff in his work also mentions the interconnection of corruption and weak institutional conditions. From a brief review of the literature dealing with the negative impact of corruption on the economic performance of countries, it is clear that the relationship between corruption and economic performance is not straightforward and it's influenced by many other factors, will go through a range of transmission channels.

On the other hand, there exist authors who have the opinion that corruption ,greases wheels“ of the economy because it enables individuals to avoid administrative delays and bureaucratic 
stays. Among the authors of studies confirming the positive effects of corruption belong e.g. Leff (1989) claims that corruption allows entrepreneurs to avoid lengthy bureaucratic procedures, thus denies the harmful effects of bureaucracy. According to Shleifer and Vishny (1993) corruption allows private agents to buy their way out of the politically forced inefficiencies. Liu (1985) used a model of sequential processing queues to prove that corruption allows rearranging the queue in terms of efficient use of time for those for whom is time so valuable that it is worthwhile to use corrupt practices to move forward. According to Leff (1989) corruption can be used to ensure that the projects and contracts were awarded in the most efficient firms. This conclusion is based on the opinion that only capable and efficient unit has sufficient funds for any corrupt activities.

All studies mentioned above have in common that they are exploring the issue of corruption at the state level. Regional view on the consequences of corruption, especially in economic terms, is still quite unexplored territory worldwide. There have been written only a few studies focused on quantifying the extent of corruption and its impact on the regional level abroad (eg. Del Monte and Papagni, 2007; Golden and Picci, 2005). According to these studies the level of corruption is in a variety of subnational division very diverse and its analysis can help explain differences in the different economic performance of regions.

\subsubsection{Regional economic performance and its indicators}

The main terms in assessing performance are efficiency and effectiveness. Peter Drucker (2008) believes that there is no efficiency without effectiveness, because it is more important to do well what you have proposed (the effectiveness) than do well something else that was not necessarily concerned. The relationship between efficiency and effectiveness is that of a part to the whole, the effectiveness is a necessary condition to achieve efficiency. Efficiency should be viewed in terms of how resources are used to achieve objectives. It is applying these inputs in such a way as to maximize their contribution to outputs. Effectiveness should be viewed in terms of the extent to which the service provided meets the objectives and/or expectations of the citizens. Waste of public funds which occurs by corrupt practices thus leading to an increase in inputs and therefore reduction of efficiency. Improper use of public funds can lead to the production of public goods and services that do not meet the requirements of citizens and therefore also tends to reduction of effectiveness. Therefore corrupt practices act to reduce the productivity of the entity. From the regional point of view the economic performance is one of the key aspects of its viability and its evaluation in context of determining its position among the other regions. Regional performance characterizes the ability of regions to generate income and to maintain employment levels in the context of national and international competition. In this connection most of strategic and tactical development activities are also directed of regional policy of countries. The European Union and the Czech Republic specialise in helping regions which lag behind the others, over the last few years they mostly they have been helping mostly regions laggging behind the given standard.

From the mentioned above it is clear that the issue of quantification corruption and its consequences at the regional level is a topic that deserves a greater attention.

The economic performance of the region is the result of many factors linked to specific local conditions, history of development of the economic base of the region and its ability to respond to external stimuli. It is characterized by gross domestic product (GDP) per capita. When conduct analysis it is not possible to focuse solely on GDP. The main drawback of regional GDP per capita is the fact that the GDP value, which is determined by "place of work" refers to the population by residential access. But the opinions that interpret other 
indicators, along with GDP, and thus refine the analysis of the economic performance of the region tend to be different. Due to the limitations of GDP per capita for regional comparisons of economic prosperity of the inhabitants of the EU regions determined relatively closer indicator of net disposable income (NDI) per capita of permanent residents in the regions. $\mathrm{NDI} /$ capita amount that households can give to final consumption, savings in the form of financial assets and the accumulation of tangible and intangible assets.

As an indicators of economic performance there are selected indicators defined in regional accounts of the Czech Statistical Office and Regional Development Strategy of the Czech Republic. Selected indicators of economic performance are gross domestic product per capita of the region (mil. CZK), net disposable income of households per capita (mil. CZK), gross added value (mil. CZK), gross fixed capital formation at 1 resident (CZK), foreign direct investment (mil. CZK), regional labor market indicators - the number of employees and the general unemployment rate (\%) (Czech Statistical Office, 2015).

\section{Quantification of corruption rate at the subnational level}

The indicators of corruption measurement which are currently used are to a larger extent based on so-called "soft data" and focus on assessing corruption at the country. Due to the absence of any method for determining corruption in a more or less affected sub-national region, the next section will present a method for quantifying corruption at a sub-national level. The design of this method is based on the construction of the European Quality of Government Index developed by the European Commission together with The Quality of Government Institute.

\subsection{The European Quality of Government Index}

The European Quality of Government Index (EQI) was created to quantify the quality of public administration at a regional level. This index has so far been worked out twice; in 2010 and 2013. 27 EU Member States were included in the EQI in 2010. In 2013, 28 EU Member States were included as well as the Candidate States, Turkey and Serbia; 30 countries in total. In 2013, the European Commission recalculated the RIC 2010 also for countries which had been newly included in the RIC 2013. The European Commission plans to construct an EQI regularly every three years. The next EQI calculation will be published in 2016. In addition to the national evaluation of the quality of governance, the resulting EQI also takes note of the evaluation of regional administration using regional data which the European Commission has drawn up for the purpose of constructing the EQI. The EQI is a combined index and consists of two major parts. The first part of the EQI takes into account the national government level, which is represented by the Worldwide Governance Indicators (WGI) of the World Bank. Of the six pillars of the quality of governance, the European Commission chose four for the construction of the EQI: Voice and Accountability (GM1), Government Effectiveness (GM3), Rule of Law (GM5) Control of Corruption (GM6). (European Comission, 2013; Kaufmann, Kraay, Mastruzzi, 2015) The second part of the EQI, which takes into account the regional level of governance, was compiled by the European Commission on the basis of a unique regional survey, conducted for the sole purpose of creating a Regional indicator of government quality, which would take into account regional aspects in the final construction of the EQI.

This unique research registered in the first construction of the EQI was executed in 172 NUTS II regions in 18 countries of the European Union in 2010 (from the remaining 9 countries of the European Union only data at the national level was included). The research includes altogether 181 regional units. Data was obtained by means of surveying more than 33000 
inhabitants. The all-European regional research was conducted from $15^{\text {th }}$ December 2009 to $1^{\text {st }}$ February 2010 by means of telephone interviews with respondents older than 18 years and in the local language. In the second construction of EQI, it was executed in 206 NUTS regions in 24 countries of the European Union in 2013 (from the remaining 7 countries of the European Union only data at the national level was included). The research includes altogether 213 regional units. Data was obtained by means of research of more than 85000 inhabitants. A list of survey questions is contained in the European Commission's document Measuring Quality of Government and Sub-National Variation (2013).

The resulting regional quality of administration indicator reflects the actual experience of respondents with the use of individual public services, thus the quality of governance in the region is evaluated as it is perceived by its inhabitants; e.g., the recipients of public administration. The Regional indicator of government quality is composed of 16 separate indicators relating to the quality of administration in a particular region. These 16 indicators were developed based on 16 questions developed in accordance with the pillars arising from the methodology of the WGI: Voice and Accountability, Government Effectiveness, Rule of Law and Control of Corruption. In order to capture the most important sub-national differences, questions were focused on three public services that are often funded or administered at sub-national levels. Each of the four pillars mentioned thus involves issues relating to education, health care and law enforcement in the region. With a focus on these three services, respondents were asked to assess these public services with regard to the three fundamental concepts of quality administration - quality, impartiality and corruption. These three concepts are the pillars of the resulting regional indicator of quality government. Data is aggregated three times using a simple average. First is the creation of the average values of responses to the questions. This will create 16 indicators for each region. Then these 16 values are aggregated into three defined pillars - quality, impartiality and corruption. Finally, these three pillars are aggregated into a single numerical Regional quality of administration indicator. A simple diagram of the formation of the Regional indicator of government quality is shown in Figure 1.

Figure 1: Approach to creating a Regional Indicator of Government Quality

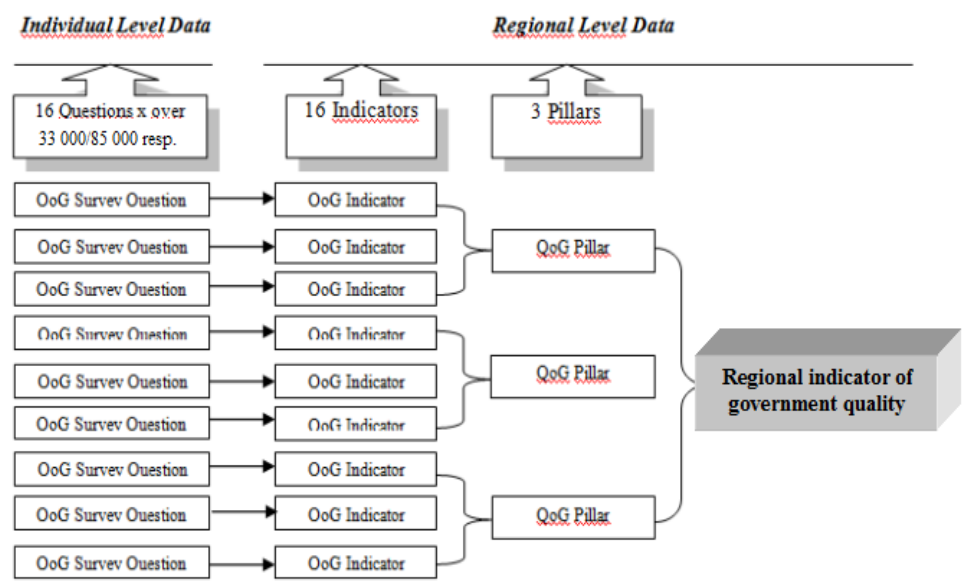

Source: own processing based on EUROPEAN COMMISSION (2013)

The final index of government quality EQI upgrades in this way national evaluation of government quality created by the World Bank by regional extent. For the purpose of findings to what extent e.g. demographic changes will display in the final value of "Regional indicator of government quality" was made a sensitivity test. It resulted from 62 executed simulations 
that though some investigated topics could be dependent on demographic conditions of a region; a change of these conditions would not expressively influence the final score of Regional indicator of government quality. The final form of the index construction is as follows:

$$
E Q I_{\text {regionXincountry } Y}=W G I_{\text {countryY }}+\left(R_{\text {qogregionXincountryY }}-C R_{\text {qogcountryY }}\right) \text {, }
$$

where $E Q I_{\text {regionXincountryY }}$ is the final European Quality of Government Index in the region of a given country,

$W G I_{\text {countryY }}$ is the national average of the above four Worldwide Governance Indicators for each country,

$R_{\text {qogregionXincountryY }}$ is the score from a regional survey; thus the Regional indicator of government quality,

$C R_{\text {qogcountryY }}$ is the regional survey of all regions in the country weighted by the proportion of the population of each region to the national population of the country.

\subsection{Regional Corruption Measurement}

The above mentioned methodology of calculating the EQI construction is today a unique approach which enables a view not only of a national but also a regional level when assessing government quality. We can assume that today it is an original approach which could be used not only for the purposes of evaluating the government quality in the future. In the context of the subject of our interest, the fact that the EQI represents the approach which allows the consideration of regional corruption is determinative in this way. Therefore from our point of view, it is possible to apply the modified form of the EQI only for the purpose of quantifying a regional rate of corruption based on the above mentioned methodology of composition of the EQI. The resulting Regional Index of Corruption (RIC) is then calculated based on the formula:

$$
R I C_{\text {regionXincountryY }}=\mathrm{CC}_{\text {countryY }}+\left(P C_{\text {qogregionXincountryY }}-C P C_{\text {qogcountryY }}\right) \text {, }
$$

where $R I C_{\text {regionXincountryY }}$ is the resulting Regional Index of Corruption for each region of a given country,

$C C_{\text {countryY }}$ is the national indicator value of Control of Corruption (GM6) from the Worldwide Governance Indicators,

$P C_{\text {qogregionXincountryY }}$ is the score from a regional survey focused on corruption, thus Pillar of Corruption,

$C P C_{\text {qogcountry }}$ is the value for the Pillar of Corruption from the regional survey of all regions in a country weighted by the proportion of the population in each region on the national population of the country.

Using the program Statistica 12 there were created graphical models of RIC variability in 30 valuated countries for years 2010 and 2013. Box plots use the method of min-max comparison and show the range of RIC values labeled the best and the worst evaluated NUTS II region. On the $\mathrm{x}$-axis there are plotted states on the y-axis RIC values. The range of RIC values is complemented by the final value of RIC of the country, which is represented by the symbol of the star. The higher the RIC value, the better the rating. A higher index value means therefore a lower the level of corruption in an area.

Figure 1 shows the range of RIC 2010 values. The greatest variability reaches assessment of corruption in Italian regions. Most corrupted Italian region is Campania (ITF3), while the best rating reached Umbria (ITE2). High variability was also found in Romania, France and Netherlands. Rating corruption at the national level can be distorting for these countries. In 
the Czech Republic mid variability of RIC 2010 was found. Figure 2 shows the range of RIC 2013 values. The region with the lowest level of corruption was Finnish Aland (FI20) with a value of 2,3932. The most corrupted region was a Bulgarian Yugozapaden (BG41) with a value of $-2,5237$. High variability of level of regional corruption was detected again in Italy, as well as Bulgaria, Turkey and Romania. The inhabitants of these coutries have different opinions about the level of corruption in their regions and the national corruption evaluation may not correspond to the actual situation in some regions. In contrast, in Danish, Swedish, Irish and Croatian regions there were detected only very small deviations in the RIC 2013 values and evaluation of the national level of corruption relevantly reflects also the evaluation of individual NUTS II regions.

Figure 1: Box plot of the Regional index of corruption 2010

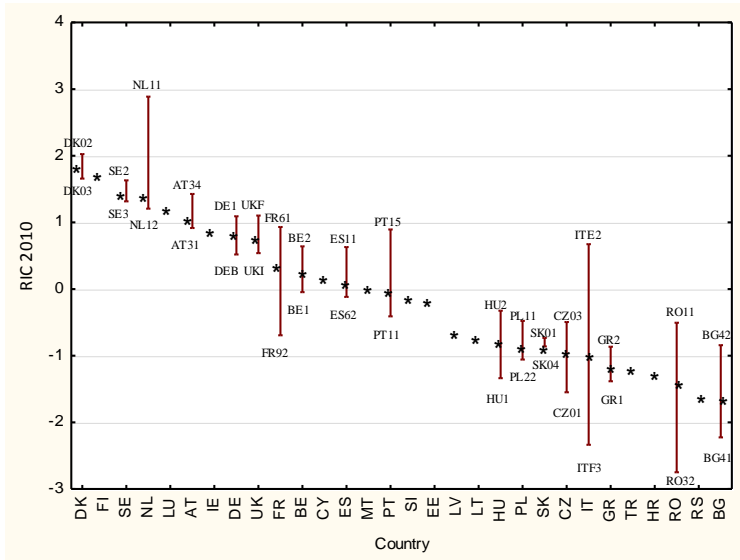

Source: own processing

Figure 2: Box plot of the Regional index of corruption 2013

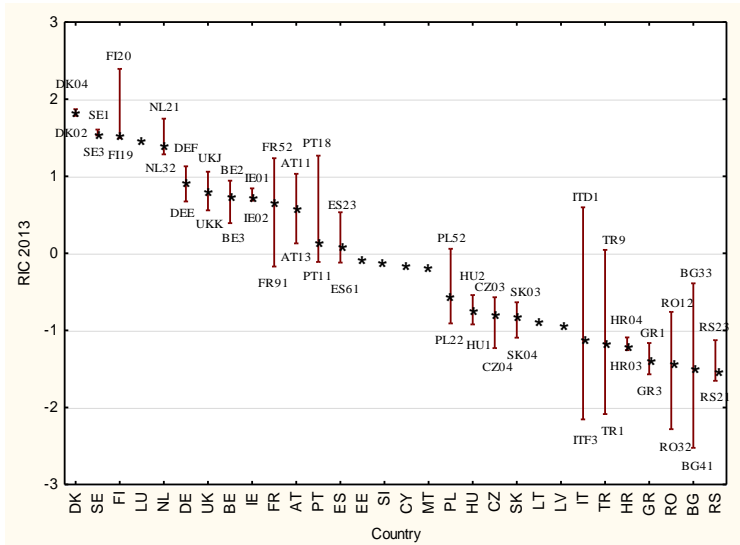

Source: own processing

The highest variability of the regional corruption rate was found in Italian regions in both Regional indexes of corruption. In Italy, as one of the countries, several studies focusing on topic of regional corruption have been written. Del Monte and Papagni (2007), Fiorno, Galli and Petrarca (2012) in their studies claim that the variability in the level of corruption in Italian regions is very variable. It is possible to find Italian regions with the very high level of corruption and regions with much lower levels of corruption as well. According to the authors Fiorno, Galli and Petrarca the most corrupted regions are Campania and Sicilia. Rating RIC for the years 2010 and 2013 in principle is the same in the conclusions of these authors. 


\section{Corruption and its impact on the economic performance of the regions of the Czech Republic}

The Regional index of corruption was for individual Czech regions calculated for the period 2009 - 2013. NUTS 2 regions will be analyzed due to the use of Regional index of corruption which is focused on quantification of corruption rate in these regions. Period of $2009-2013$ is used due to the period of data collection. Rating of Czech regions is shown in the following Figure 3.

Figure 3: Regional index of corruption in the period 2009-2013

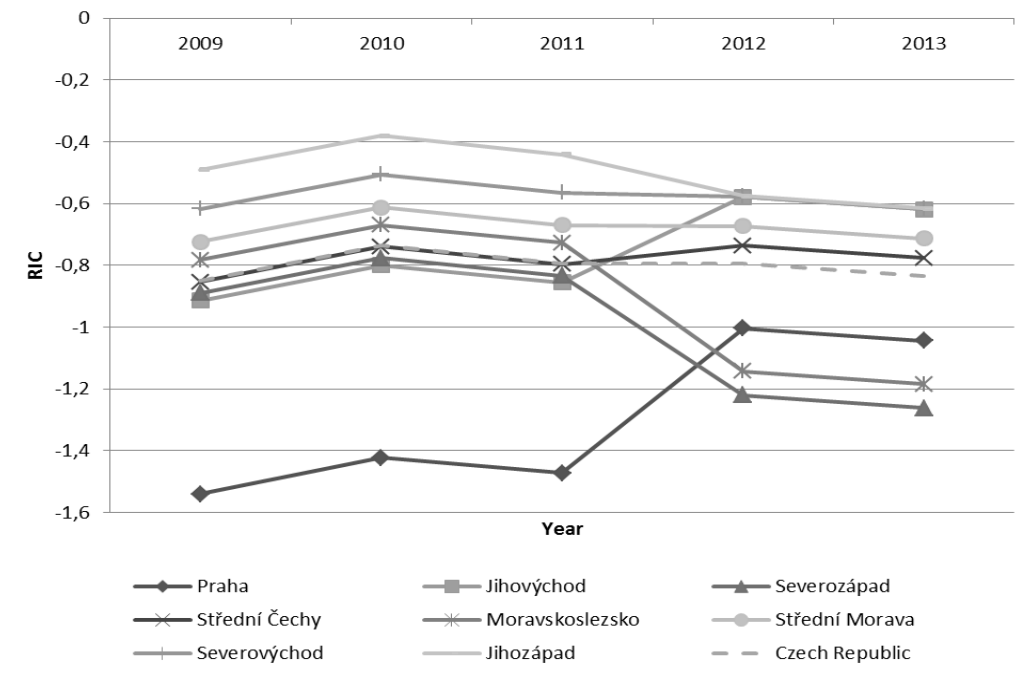

Source: own processing

The dashed line represents the national ratings of RIC. Regions located below this line are thus regions with below-average evaluations, ie regions more affected by corruption. On the other hand, regions located above this line are thus regions with above-average rating, ie regions less affected by corruption. Because of this variability, it could be misleading to evaluate the country as a whole from the viewpoint of the level of corruption. The development of RIC shows highly deteriorating evaluation of Severozápad and Moravskoslezsko regions in the valuated period.

Corruption crimes in period 2009 - 2013 were examined as well. The largest volume of corruption crimes was found in Prague cohesion region. The volume of corruption criminal cases in Prague are getting every year closest to a region of the Severozápad (Policie ČR, 2015). The region even in bribery offenses Praha in recent years surpassed. In no other region of cohesion it was not in 2012 and 2013 Czech police discovered many offenses direct, indirect bribery and accepting a bribe as being in the Severozápad region. So-called "Carlsbad losovačka" which is associated with the region, became very famous. Confederation of Industry of the Czech Republic carried out the 2013 survey in the regions, whose aim was to highlight the main challenges of the business environment in individual regions. Now in Severozápad regions perceive companies and entrepreneurs degree of red tape as a major challenge to their business (Svaz průmyslu a dopravy ČR, 2013).

\subsection{Correlation analysis of the relationship between corruption and economic performance indicators}

The correlation analysis was carried out in order to verify the relationship between corruption and economic performance indicators for each of the eight NUTS II regions of the Czech 
Republic. Firstly it was tested assuming a normal distribution of individual data sets for each region. Executed Saphiro-Wilk test did not confirm the normality of a large number of indicators. Hence it was used nonparametric variant of correlation analyzes. The basic tool for revealing the relationship between corruption and economic performance was the Spearman's correlation coefficient. A statistically significant correlation relationship between corruption and GDP/capita, GAV and FDI has been confirmed in this case of correlation analysis. Statistically significant relationship between corruption and economic performance indicators was found in the regions of the Jihozápad, Severozápad and Moravskoslezsko. Results of correlation analysis for all Czech regions are shown in Table 1.

Table 1: Results of the correlation analysis

\begin{tabular}{|c|c|c|c|c|c|c|c|c|}
\hline $\begin{array}{l}\text { Variable/ } \\
\text { NUTS II }\end{array}$ & 跑 & 玹 & U & 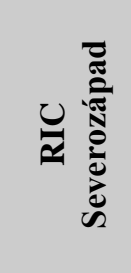 & 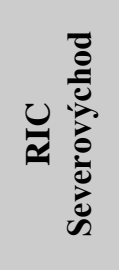 & 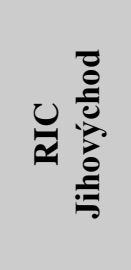 & 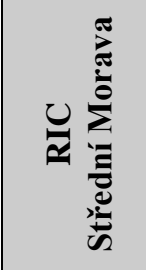 & 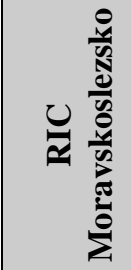 \\
\hline GDP/capita & $-0,6000$ & 0,3000 & $-0,9000$ & 0,5000 & 0,6000 & 0,6000 & 0,8000 & $-0,90000$ \\
\hline Gross Aded Value & $-0,6000$ & $-0,6000$ & $-0,9000$ & 0,8000 & 0,3000 & 0,8000 & 0,6000 & $-0,6000$ \\
\hline NDI/capita & 0,3000 & 0,6000 & $-0,3000$ & 0,5000 & 0,0000 & 0,3000 & 0,6000 & $-0,6000$ \\
\hline $\begin{array}{l}\text { Gross fixed capital } \\
\text { formation /cap. }\end{array}$ & 0,0000 & 0,6000 & 0,7000 & $-0,1000$ & 0,000 & 0,000 & $-0,6000$ & $-0,7000$ \\
\hline FDI & 0,7000 & 0,6000 & $-0,6000$ & 0,9000 & 0,3000 & 0,8000 & 0,8000 & $-0,6000$ \\
\hline Unemployment rate & $-0,1539$ & $-0,3000$ & $-0,1539$ & $-0,1000$ & 0,3000 & 0,6000 & $-0,15390$ & $-0,5000$ \\
\hline No. of employees & $-0,7000$ & 0,6000 & 0,5000 & 0,5000 & 0,866 & 0,3000 & 0,000 & $-0,3000$ \\
\hline
\end{tabular}

Source: own processing

3.2 Regression analysis of the impact of corruption on regional economic performance The correlation analysis of variables does not allow to decide which of the variables is the dependent variable and which is the independent variable. Confirmation of the impact of corruption on economic indicators, or determining the extent of this effect, is possible by using the regression analysis. The regression analysis was due to meet the assumptions of the model perform for the effect of corruption on GDP/capita in the Jihozápad region and the impact of corruption on FDI in the Severozápad region. The regression analysis was performed for the period 2009-2013. Figure 4 shows the linear regression model of the Jihozápad region. Results of the regression analysis confirm the negative relationship between the Regional index of corruption and the indicator of GDP/capita in the Jihozápad region. This conclusion is consistent with theories that suggest positive effect of corruption on economic performance of the state. Higher level of corruption positively affected economic performance in the region in the analyzed period. Table 2 contains detailed regression results. 
Figure 4: Graphical representation of the regression function for the Jihozápad region

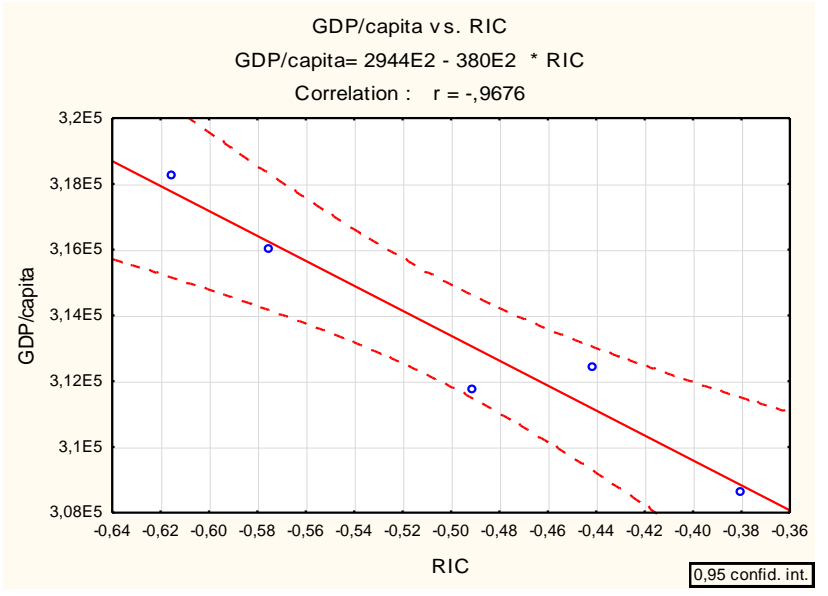

Source: own processing

Table 2: Results of the regression analysis for the Jihozápad region

\begin{tabular}{|c|c|c|c|c|c|c|}
\hline \multirow[t]{2}{*}{$\mathrm{N}=5$} & \multicolumn{6}{|c|}{$\begin{array}{c}\text { Regression results with the dependent variable: GDP/cap. } \\
R=0,96761436 \quad R^{2}=0,93627756 \text { Adj. } R^{2}=0,91503674 \\
F(1,3)=44,079 p<0,00696 \\
\text { Standard error of estimate: } 1095,0\end{array}$} \\
\hline & $b^{*}$ & $\begin{array}{c}\text { St.dev. } \\
\left(b^{*}\right)\end{array}$ & b & $\begin{array}{l}\text { St.dev. } \\
\text { (b) }\end{array}$ & $\mathrm{t}(3)$ & $p$-value. \\
\hline Abs.value & & & 294420,3 & 2900,016 & 101,5237 & 0,000002 \\
\hline RIC & $-0,967614$ & 0,145742 & $-37926,0$ & 5712,422 & $-6,6392$ & 0,006962 \\
\hline
\end{tabular}

Source: own processing

A comparison of $p$-values with a significance level of 0,05 indicates that the null hypothesis H0: $\beta=0$ can be rejected. The effect of corruption on GDP/capita in the region Jihozápad was proven in the evaluation period. Specifically, improvement of the Regional index of corruption value by one unit caused a fall in GDP/capita an average of $37926 \mathrm{CZK}$ during the analyzed period.

Statistically significant positive effect of corruption on foreign direct investment was detected in the Severozápad region. Figure 5 shows the linear regression model of dependence of FDI on corruption expressed by the Regional index of corruption in the Severozápad region. The regression analysis confirmed a positive relationship between the Regional index of corruption and foreign direct investment in the Severozápd region. These findings are consistent with studies that argue about the negative impact of corruption on economic performance. Table 3 contains detailed regression results. 
Figure 5: Graphical representation of the regression function for the Severozápad region

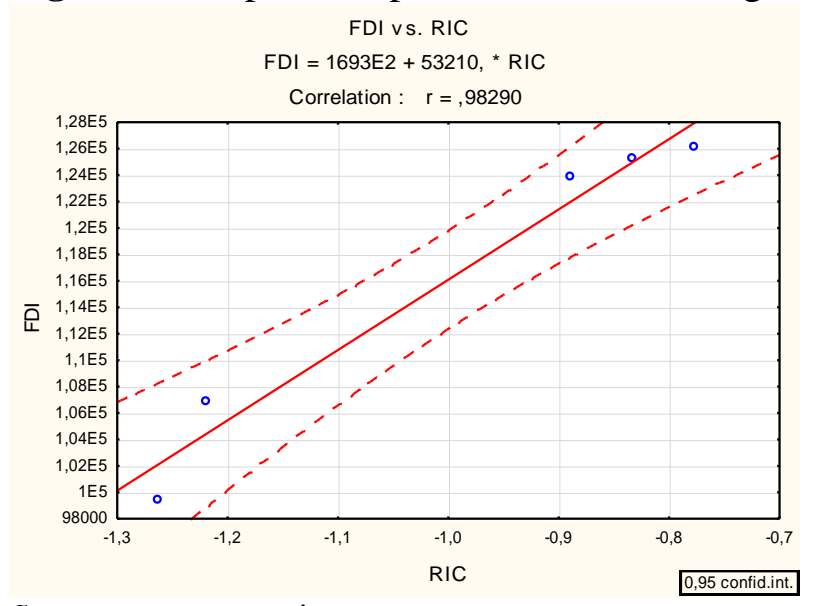

Source: own processing

Table 3: Results of the regression analysis for the Severozápad region

\begin{tabular}{|c|c|c|c|c|c|c|}
\hline \multirow[t]{2}{*}{$\mathrm{N}=5$} & \multicolumn{6}{|c|}{$\begin{array}{c}\text { Regression results with the dependent variable: FDI } \\
\mathrm{R}=0,98290272 \quad \mathrm{R} 2=0,96609775 \quad \text { Adj. } \mathrm{R}^{2}=0,95479700 \\
\mathrm{~F}(1,3)=85,490 \mathrm{p}<0,00268 \\
\text { Standard error of estimate: } 2616,8\end{array}$} \\
\hline & $\mathrm{b}^{*}$ & $\begin{array}{c}\text { St.dev. } \\
\left(b^{*}\right)\end{array}$ & b & $\begin{array}{l}\text { St.dev. } \\
\text { (b) }\end{array}$ & $\mathrm{t}(3)$ & $p$-value \\
\hline Abs.value & & & 169298,6 & 5851,079 & 28,93459 & 0,000091 \\
\hline RIC & 0,982903 & 0,106305 & 53210,1 & 5754,894 & 9,24606 & 0,002677 \\
\hline
\end{tabular}

Source: own processing

A comparison of p-values with a significance level of 0,05 indicates that the null hypothesis H0: $\beta=0$ can be rejected. The effect of corruption on FDI in the Severozápad region was proven in the analyzed period. The worse evaluating of corruption caused a decline of value of FDI in the Severozápad region. This reduction in value of the Regional index of corruption specifically resulted in a decrease of foreign direct investment on average of $53210 \mathrm{CZK}$. Such a conclusion is consistent with a group of theories that argue with a negative effects of corruption on economic performance of the area.

\section{Conclusion}

Although the issue of corruption has been a very fresh topic, this topic is very neglected at the regional level. The main reason is a lack of data. Due to the different socio-economic development of regions it can be assumed that even a corrupted environment in these regions differ.

In accordance with studies that confirm the relationship between corruption and economic performance at the national level, this relationship can be confirmed also at the regional level of the Czech Republic. Based on the values of the Regional index of corruption, it was found that the level of corruption is in Czech NUTS II regions heterogeneous and identified more and less affected areas. The regions Jihozápad, Severozápad and Moravskoslezsko were defined as a regions with the strongest relationship between corruption and indicators of economic performance. In the Jihozápad region was by regression analysis proved the impact of corruption on the GDP/capita and in the Severozápad region was proved the impact of corruption on the foreign direct investment. At the same time it can be said that there has not been refuted any group of theories about an impact of corruption on economic performance. 
Not only due to a short time series of the Regional index of corruption this article does not attempt to strictly define a degree of influence of corruption on economic performance in Czech NUTS II regions. However, previous text outlines the way how to define and quantify the exact impact of corruption on economic performance in NUTS II regions not only in the Czech Republic. At the current level of knowledge, the ability to quantify the extent of corruption at a sub-national level fills a gap that, within the general issue of corruption still exists, both in the Czech Republic and worldwide. Exposing corruption in today's globalised environment is becoming more complex and it is an issue even for countries that generally achieve relatively good results. It is therefore necessary to continue charting corruption and prevent its further expansion. The present article only opens another direction of scientific research in this field. It can be assumed that extending the time scale will allow the Regional Corruption Index further research in this area, especially with regard to the need for a practical application of the proposed methodology at the level of authentic regions. The possibility of defining regions more affected by corruption would allow to concentrate tools of anti-corruption politics mainly on regions which are mostly affected by corruption and this would create a new tool for elimination of regional disparities. Diversification of individual regions of aggregation would also pose valuable benefit for current anti-corrupt politics of a country. Individual tools of anti-corruption politics could be so focused mainly on spheres which will be evaluated as the most problematic ones.

Determining regions more or less affected by corruption provides a basis for more detailed analysis of specific NUTS II regions including concrete proposals for anti-corruption activities in specific regions. Further research of the author of this article will be oriented in this direction.

\section{References}

[1] CORDER, G. W. and D. I. FOREMAN, 2009. Nonparametric Statistics for NonStatisticians: A Step-by-Step Approach. New York: Wiley. ISBN 978-0-470-45461-9

[2] CZECH STATISTICAL OFFICE, 2015. Ukazatele v regionálním členění [online]. [vid. 12. April 2016]. Databáze regionálních účtů. Accessible from: apl.czso.cz/pll/rocenka/rocenkavyber.volba?titul=Ukazatele\%20v\%20region\%E1ln\%ED $\mathrm{m} \% 20 \% \mathrm{E} 8 \mathrm{len} \% \mathrm{ECn} \% \mathrm{ED} \& \mathrm{mypriznak}=\mathrm{RC} \& \mathrm{typ}=2 \& \mathrm{proc}=$ rocenka.presmsocas\&mylang $=\mathrm{CZ} \& \mathrm{jak}=4$

[3] DEL MONTE, A. and E. PAPAGNI, 2007. The Determinants of Corruption in Italy: Regional Panel Data Analysis. European Journal of Political Economy, 23, 379-396. ISSN 0176-2680.

[4] DRUCKER, P. F., 2008. The Essential Drucker: The Best of Sixty Years of Peter Drucker's Essential Writings on Management. HarperBusiness. ISBN 978-0061345012.

[5] EUROPEAN COMMISSION, 2013. Measuring Quality of Government and SubNational Variation. Regional Policy [online]. [vid. 23. March 2016]. Accessible from: ec.europa.eu/regional_policy/sources/docgener/studies/pdf/2010_government_1.pdf

[6] FIORINO, N., E. GALLI and I. PETRARCA, 2012. Corruption and Growth: Evidence from the Italian regions. European Journal of Government and Economics, 1(2), 126144. ISSN 2254-7088

[7] GOLDEN, M. and L. PICCI, 2005. Proposal for a New Measure of Corruption, Illustrated with Italian Data. Economics \& Politics, 17(1), 37-75. ISSN 1468-034. 
[8] HUNTINGTON, S. P., 1968 Political Order in Changing Societies. New Haven: Yale University Press. ISBN 0-300-01171-7.

[9] CHARRON, N., D. LEWIS and V. LAPUENTE, 2015. Mapping the Regional Divide in Europe: A Measure for Assessing Quality of Government in 206 European Regions. Social Indicators Research, 122(2), 315-346. ISSN 0303-8300.

[10] KAUFMANN, D., A. KRAAY and M. MASTRUZZI, 2015. Governance Matters IV: Governance Indicators for 1996-2004 [online]. [vid. 21. March 2016]. Accessible from: siteresources.worldbank.org/INTRES/Resources/469232-1107449512766/GovMatters IV_main.pdf

[11] LAMBSDORFF, J. G., 2001. How Corruption in Government Affects Public Welfare - A Review of Theories. Discussion Papers, 9, 43. Center for globalisation and europeanisation of the economy, Volkswirtschaftliches Seminar 2001. ISSN 1439-2305.

[12] LEFF, N. H., 1989. Economic Development through Bureaucratic Corruption. In: A. J. HEIDENHEIMER et al., eds. Political Corruption - A Handbook. New Brunswick: Transaction Publisher, p. 389-403. ISBN 0-88738-163-4.

[13] LEITE, C. and J. WEIDMANN, 1999. Does Mother Nature Corrupt - Natural Resources, Corruption and Economic Growth [online]. IMF Working Paper No. 85 [vid. 12. April 2016]. Washington: International Monetary Fund. Accessible from: www.imf.org/external/pubs/ft/wp/1999/wp9985.pdf

[14] LIU, F. T., 1985. An Equilibrium Queuing Model of Grubery Games. Journal of Political Economy, 93(4), 760-781. ISSN 0022-3808.

[15] MAURO, P., 1995. Corruption and Growth. Quarterly Journal of Economics, 110(3), 681-712. ISSN 0033-5533.

[16] MO, P. H., 2001. Corruption and Economic Growth. Journal of Comparative Economics, 29(1), 66-79. ISSN 0147-5967.

[17] NYE, J. S., 1967. Corruption and Political Development: A Cost-Benefit Analysis. American Political Science Review, 67(2), 963. ISSN 0003-0554.

[18] POLICIE ČR, 2015. Statistické přehledy kriminality [online]. [vid. 23. March 2016]. Accessible from: www.policie.cz/statistiky-kriminalita.aspx

[19] SHLEIFER, A. and R. W. VISHNY, 1993. Corruption. The Quarterly Journal of Economics, 108(3), 599-617. ISSN 0033-5533.

[20] SVAZ PRŮMYSLU A DOPRAVY ČR, 2013. Šetřenív krajích [online]. [vid. 12. April 2016]. Accessible from: www.spcr.cz/ankety/setreni-v-krajich-2013

[21] TANZI, V. and H. DAVOODI, 1997. Corruption, Public Investment, and Growth [online]. IMF Working Paper 97/139 [vid. 12. April 2016]. Washington: International Monetary Fund. Accessible from: www.imf.org/external/pubs/ft/wp/wp97139

[22] TRANSPARENCY INTERNATIONAL, 2013. Corruption Perceptions Index 2013 [online]. [vid. 12. April 2016]. Accessible from: www.transparency.org/cpi2013/

[23] VOLEJNÍKOVÁ, J. and V. LINHARTOVÁ, 2014. Macroeconomic aspects of corruption. Saarbrücken: LAP Lambert Academic Publishing, 72 p. ISBN 978-3-65952992-4. 